\title{
The effects of octreotide in a patient with Nelson's syndrome
}

\author{
Fahrettin Kelestimur, Cengiz Utas, Ömer Özbakir, Ahmet Selçuklu, Olcay Kandemir, \\ Nevzat Özcan
}

\begin{abstract}
Summary
We have administered octreotide, $100 \mu \mathrm{g}$ tid, to a 27-year-old man with Nelson's syndrome. After seven days of therapy, adrenocorticotropin levels fell to $54 \%$ of initial values, and some shrinkage of the tumour was observed. This study indicates that octreotide therapy may have a role in the treatment of Nelson's syndrome.
\end{abstract}

Keywords: octreotide, Nelson's syndrome

Nelson's syndrome is a rare condition now as a result of the advent of pituitary microsurgery for Cushing's disease. These tumours are rather invasive and need urgent treatment. Pituitary surgery is the first line treatment, although pituitary irradiation has been suggested as primary or secondary therapy. ${ }^{1}$ Some tumours are not responsive and carry a poor prognosis. Somatostatin has been shown to be effective in the inhibition of adrenocorticotropin release by the cultured pituitary cells in a patient with Nelson's syndrome. ${ }^{2}$ However, there are a few reports about the effects of the long-acting somatostatin analogue octreotide (SMS 201-995) on adrenocorticotropin secretion in Nelson's syndrome. Recently we had the opportunity to investigate the effect of octreotide on adrenocorticotropin secretion and tumour size in a patient with Nelson's syndrome.

\section{Case report}

Erciyes University Medical School, 38039 Kayseri-Turkey

Department of Internal Medicine (Endocrinology)

F Kelestimur

CUtas

ÖÖzbakir

Department of

Neurosurgery

A Selçuklu

Department of

Pathology

O Kandemir

Department of

Radiology

NÖzcan
A 27-year-old man who underwent total bilateral adrenalectomy for Cushing's disease in 1987 in another hospital was admitted to our hospital because of skin pigmentation. He had been on prednisolone, $5 \mathrm{mg}$ a day, since 1987 . $\mathrm{He}$ had recently noticed increased pigmentation and muscle weakness. On physical examination, blood pressure was 100/ $60 \mathrm{mmHg}$, pulse rate 80 beats $/ \mathrm{min}$. He was hyperpigmented. Laboratory investigations showed fasting blood glucose $3.9 \mathrm{mmol} / \mathrm{l}$, sodium $125 \mathrm{mmol} / \mathrm{l}$, potassium $6.3 \mathrm{mmol} / \mathrm{l}$, chloride $91 \mathrm{mmol} / \mathrm{l}$, serum urea $4.9 \mathrm{mmol} / \mathrm{l}$, creatinine $88.4 \mathrm{mmol} / \mathrm{l}$, liver function tests within normal limits. Baseline hormone levels were as follows: prolactin $4.50 \mu \mathrm{g} / 1(3.3-10)$; follicle-stimulating hormone $5.63 \mathrm{IU} / 1(4-10)$; luteinising hormone $3.01 \mathrm{IU} / 1$ (1-8); free triiodothyronine $2.24 \mathrm{pmol} / 1$ (2.1-6.1); free thyroxine $17.24 \mathrm{nmol} / 1 \quad(10-25)$; thyroidstimulating hormone $2.32 \mathrm{mU} / 1$ (0.6-4.6); adrenocorticotropin $\quad 56.4 \mathrm{pmol} / 1 \quad(0-8.1)$, repeated $84.3 \mathrm{pmol} / 1$. Computed tomography (CT) scan of the pituitary fossa showed suprasellar extension of the pituitary tumour. The diameter of the tumour was $18.7 \mathrm{~mm}$ (figure 1). We decided to treat the patient by transsphenoidal microsurgery which is the first choice of therapy, but before surgery we administered octreotide to investigate its effectiveness in decreasing adrenocorticotropin secretion and tumour size. Before the administration of octreotide, blood samples for adrenocorticotropin detection were taken every 15 minutes for one hour in the morning between 8 and 9 am. The patient was then given octreotide at a dose of $100 \mu \mathrm{g}$ tid subcutaneously for seven days, after which blood samples for adrenocorticotropin were again taken, as mentioned above. A second CT scan of the pituitary tumour was also taken (figure 2 ). The tumour was then successfully removed by the transsphenoidal route. Using immunohistochemical techniques the tumour was found to stain strongly for adrenocorticotropin but not for growth hormone, folliclestimulating hormone, luteinising hormone, or prolactin. Histopathologic and immunohistochemical examinations confirmed Nelson's syndrome.

Mean plasma adrenocorticotropin levels before and after octreotide therapy were $66.7 \mathrm{pmol} / 1$ and $36 \mathrm{pmol} / \mathrm{l}$, respectively, a

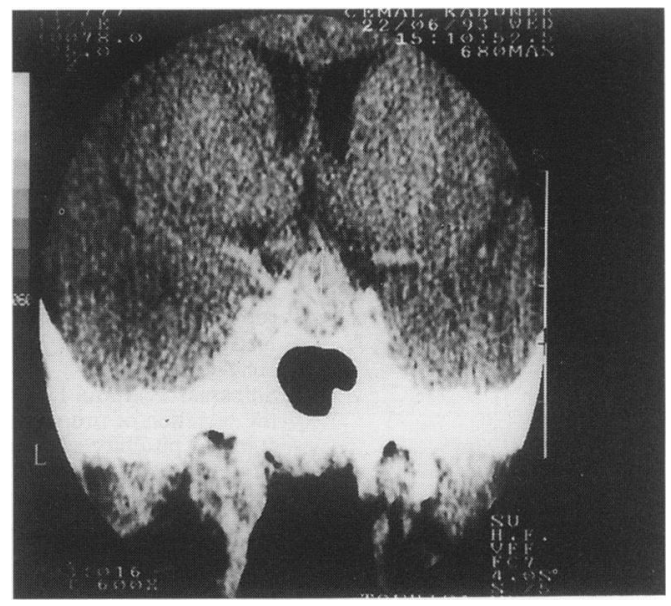

Figure 1 CT scan of pituitary tumour before treatment with octreotide 
decrease of approximately $54 \%$ (see table). Octreotide therapy also led to a 3-mm reduction in tumour diameter (as shown in figures 1 and 2).

\section{Discussion}

The treatment of Nelson's syndrome is difficult. Although pituitary microsurgery and/ or irradiation have been reported to be effective therapeutic interventions, some cases still carry a poor prognosis. ${ }^{1}$ Somatostatin, dexamethasone, bromocriptine and cyproheptadine significantly inhibited adrenocorticotropin release by cultured pituitary cells in a patient with Nelson's syndrome. ${ }^{2}$ In another study Shibasaki and Masui showed that somatostatin-14 and somatostatin-28 suppressed the secretion of propiomelanocortinderived peptides by the adenoma obtained from a patient with Nelson's syndrome. ${ }^{3}$ Some studies have shown infusion of native somatostatin to be effective in Nelson's syndrome. In one of them, Thyrrell et al infused $500 \mu \mathrm{g}$ somatostatin in one hour to five patients with Nelson's syndrome which resulted in a sustained progressive fall in plasma adrenocorticotropin levels to $40-71 \%$ of the basal values with a return toward initial levels after cessation of the infusion. ${ }^{4}$ They also concluded that somatostatin receptors are not functional or present in normal pituitary tissue, but are present in Nelson's syndrome. The degree of decrease in adrenocorticotropin level was similar to our result, ie, $48 \%$ and $54 \%$, respectively. Octreotide has been used successfully in pituitary and neuroendocrine tumours of the gut. $^{5-7}$ There are some reports of the effects of octreotide in patients with neuroendocrine tumours producing ectopic Cushing's syndrome. ${ }^{7}$ The results of these studies suggest that octreotide produces striking improvements in the syndrome of ectopic adrenocorticotropin secretion. In patients with pituitary-dependent hypercortisolism octreotide treatment resulted in no change in blood adrenocorticotropin or cortisol levels. ${ }^{8}$ It was reported that in vitro autoradiography did not demonstrate the binding of octreotide to the tumour tissue in a patient with an adrenocorticotropin-secreting pituitary adenoma. ${ }^{9}$ In contrast, the secretion of excess adrenocorticotropin in patients with pituitary adenomatous development (Nelson's syndrome) following bilateral adrenalectomy

1 Thorner MO, Vance ML, Horvath E, Kovacs K. The anterior pituitary. In: Wilson JD, Foster DW, eds. Williams textbook of endocrinology, Philadelphia: WB Saunders, 1992; pp 221-310.

2 Lamberts SWJ, Oosterom R, Verleun T, Bons EG, Uitterlinden $P$. A met-enkephalin analog inhibits adrenocorticotropin secretion by cultured pituitary cells from a patient with Nelson's syndrome. F Clin Endocrinol Metab 1981; 53: 1084-6.

3 Shibasaki T, Masui H. Effects of various neuropeptides on the secretion of propiomelanocortin-derived peptides by a cultured pituitary adenoma causing Nelson's syndrome. $\mathcal{f}$ Clin Endocrinol Metab 1982; 55: 872-6.

4 Thyrrell JB, Lorenzi M, Gerich JE, Forsham PH. Inhibition by somatostatin of ACTH secretion in Nelson's syndrome. F Clin Endocrinol Metab 1975; 40: 1125-7.

5 Kelestimur F. (Letter) Acta Endocrinol 1993; 128: 99.

6 Utas C, Kelestimur F, Boyaci A, Saglam A. Control of plasma glucose with somatostatin analogue (SMS 201-995) during surgical removal of insulinomas. Postgrad Med $\mathcal{f}$ 1993; 69: 920-1.

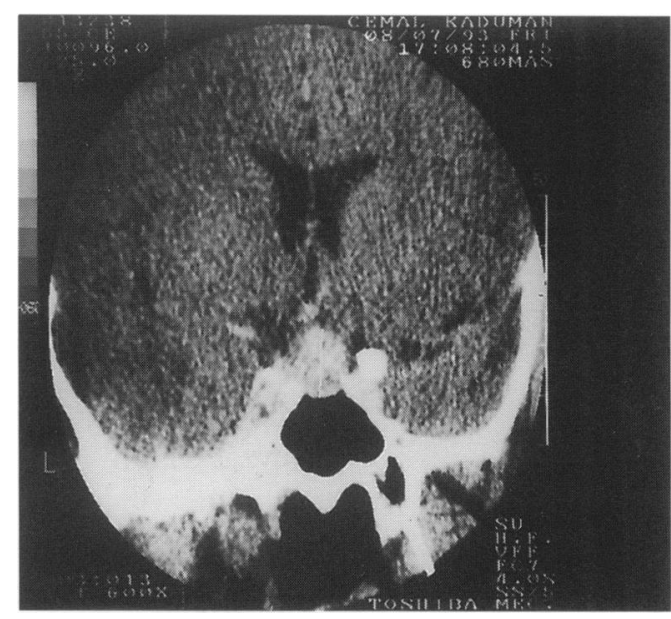

Figure 2 CT scan of pituitary tumour after treatment with octreotide

Table Adrenocorticotropin levels before and after administration of octreotide

\begin{tabular}{lll}
\hline & \multicolumn{2}{l}{ Adrenocorticotropin $(p m o l / l)$} \\
\cline { 2 - 3 } Time $(\min )$ & Before & After \\
\hline 0 & 72.7 & 24.9 \\
15 & 68.0 & 20.4 \\
30 & 65.2 & 53.9 \\
45 & 60.6 & 44.8 \\
\hline
\end{tabular}

has been shown to be suppressed by octreotide in one patient. Visual field defects were improved after six weeks of treatment despite the absence of tumour shrinkage on CT scan and continued suppression of adrenocorticotropin levels was demonstrated over two years. ${ }^{8}$ We think that variability in the concentrations of somatostatin receptors in adrenocorticotropinsecreting tumours may explain the variations in response to octreotide.

In our patient octreotide worked well and decreased adrenocorticotropin levels by at least $50 \%$ after seven days of treatment $(100 \mu \mathrm{g}$ tid). This fall in adrenocorticotropin levels may be related to the lack of negative feedback mechanism which was due to bilateral adrenalectomy, as adrenocorticotropin release by normal corticotrophs appears to be sensitive to somatostatin only in the absence of the physiological peripheral feedback regulation by glucocorticoids. ${ }^{10}$

7 Maten PN. The use of the long-acting somatostatin analogue, octreotide acetate in patients with islet cell tumors. Gastroenterol Clin N Am 1989; 18: 897-922.

8 Lamberts SWJ, Uitterlinden P, Klijn JM. The effect of the long-acting somatostatin analogue SMS 201-995 on ACTH secretion in Nelson's syndrome and Cushing's disease. Acto Endocrinol 1989; 120: 760-6.

9 Lamberts SWJ, Krenning EP, Bakker WH, Breeman WAP Kooij PPM, Reubi JC. Somatostatin receptor imaging in the diagnosis of pituitary and parasellar tumours. In: Melmed S, Robbins RJ, eds. Molecular and clinical advances in pituitary disorders. Boston: Blackwell Scientific Publications, 1990; pp 285-92.

10 Lamberts SWJ, Zuyderwijk J, den Holder F, Van Koetsveld $\mathrm{P}$, Hofland $\mathrm{L}$. Studies on the conditions determining the inhibitory effect of somatostatin on adrenocorticotropin, prolactin and thyrotropin release by cultured rat pituitary cells. Neuroendocrinology 1989; 50: 44-50. 